\title{
Optimization of the Growth and Performance of Several Cynobacteria Species in a Pilot Scale Raceway Pond for $\mathrm{CO}_{2}$ Bio-Sequestration
}

\author{
Hetarth B. Patel ${ }^{1}$, Hitesh A. Solanki²*
}

${ }^{1}$ Ph.D. Research scholar, Department of Environmental Science, Gujarat University, Ahmedabad, Gujarat, India

${ }^{2}$ Professor and Head, Environmental Science Department, Gujarat University, Ahmedabad, Gujarat, India

Article Info

Volume 8, Issue 6

Page Number : 497-509

\section{Publication Issue}

November-December-2021

\section{Article History}

Accepted : 15 Dec 2021

Published : 30 Dec 2021

\section{ABSTRACT}

Due to the limited availability of fresh water and the high cost of land for plant culture, microalgae cultivation has attracted significant attention in recent years and has been shown to be the best option for $\mathrm{CO}_{2}$ bio-sequestration. Biosequestration of $\mathrm{CO}_{2}$ through algae bioreactors has been hailed as one of the most promising and ecologically benign methods available. This research study was taken up to alleviate certain limitations associated with the technology such as low $\mathrm{CO}_{2}$ sequestration efficiency and low biomass yields. In this study three distinct cyanobacterial strains, Chlorella sp., Synechococcus sp., and Spirulina sp., were tested in 10 litre raceway ponds for their capacity for $\mathrm{CO}_{2}$ bioconversion and high biomass production under various $\mathrm{CO}_{2}$ concentrations at different EC. The highest growth rate of all tested cyanobacterial strains was observed during the first 4 days of cultivation under $\mathrm{CO}_{2} 5 \%$ to $10 \%$. Additionally, all these cyanobacterial strains were explored for their bioremediation capabilities. The results showed that the Chlorella sp., Synechococcus sp., and Spirulina sp. were able to remove COD of the wastewater by $56 \%, 48 \%$ and $77 \%$ respectively and the BOD removal efficiency was $48 \%, 30 \%$ and $52 \%$ respectively. The primary results indicated that the Spirulina sp. was to be the best cynobacteria studied in terms of biomass production, $\mathrm{CO} 2$ bioconversion, and bioremediation capacities. Therefore, the Spirulina sp. was further scaled up in 1500 litre raceway pond for $\mathrm{CO}_{2}$ bio-sequestration and biomass production. The biomass collected was utilised to extract biomolecules such as protein, carbohydrate and lipids.

Keywords : $\mathrm{CO}_{2}$ bio-sequestration, Cyanobacteria, Spirulina sp., Raceway Pond, Biosorption

\section{INTRODUCTION}

All countries are dealing with a variety of problems right now, but none is more perplexing than global warming (Lowe et al 2009). The fundamental cause of climate change was the generation of greenhouse gases (GHGs) by humans (Solomon et al., 2007). Consequently, in order to manage the emissions of 
these gases, it is vital to design technology that is both environmentally benign and cost effective. Carbon dioxide $\left(\mathrm{CO}_{2}\right)$ is the primary greenhouse gas which is the main reason for the climate change; carbon capture and storage (CCS) systems are critical components of GHGs mitigation strategies (Cao and Caldeira, 2010). As a result, various mechanisms and protocols, particularly in the case of large source emissions, are being used to reduce greenhouse gas emissions resulting from anthropological activities. Because of their potential to reduce greenhouse gas emissions, CCS technologies are included in these initiatives (Gough, 2008). A physical fixation strategy and a chemical adsorption strategy have both been proposed as ways to slow the increase in $\mathrm{CO}_{2}$ concentration. Aside from that, biological mitigation as a climate change mitigation strategy has received a great deal of attention in recent years due to the generation of secondary pollutants from these strategies.

The biofixation of $\mathrm{CO}_{2}$ achieved by microalgae and cyanobacteria has received a great deal of interest across the globe because of its high efficiency in $\mathrm{CO}_{2}$ removal (Ono and Cuello, 2006; Chang and Yang, 2003; Fan et al., 2007). A wide range of applications for the microalgal biomass that is produced, including the production of biofuels and medical supplements, can be made with this material(Arata et al., 2013). The microalgae Spirulina platensis has previously been identified as a most popular microalgae strain that has been shown to be effective in the biofixation of carbon dioxide (Carvalho et al., 2004; Zeng et al., 2012; Soletto et al., 2008). Furthermore, Spirulina is widely regarded as one of the most important sources of commercially viable renewable feedstock for the production of single cell protein and other high-value metabolites, the most notable of which is phycocyanin, which is found in high concentrations in the microalgae (Leema et al., 2010). Spirulina is also widely regarded as a potential source of single cell protein and other high-value metabolites for human consumption. This natural food is commonly used to combat malnutrition because of its high nutritional content, which is comprised of highquality proteins, carbohydrates, fats, vitamins, minerals, pigments, and antioxidants, as well as its high nutritional content. Therefore, Spirulina cultivation has expanded to rural areas in a number of developed and developing nations.

When it comes to photosynthesis, algae and green plants have developed a mechanism known as the carbon concentration mechanism (CCM). Sequestration studies, on the other hand, are preferred because CCM enhances algae growth rates (Mehar et al., 2019). The ability of cyanobacteria and microalgae to utilize dissolved inorganic carbon (DIC) has recently been the subject of numerous studies. They can change their affinity for $\mathrm{DIC}\left(\mathrm{HCO}_{3}\right.$ and $\mathrm{CO}_{2}$ ), depending on the concentration of DIC in their environment, and there is an active mechanism that allows $\mathrm{CO}_{2}$ to be concentrated inside the cell (Ghoshal et al., 2002; Riebesell et al., 2007). Climate and environmental factors such as light, temperature, nutrient status, and salinity all have an impact on photosynthesis and productivity of biomass. Biomass measurement or growth rate evaluations are required in order to determine the potential of a microalgal system for directly removing $\mathrm{CO}_{2}$. It was previously reported that the efficiencies of Spirulina biomass in raceway pits are affected by the above mentioned climate and environmental factors. The $\mathrm{pH}$ of a solution is important for cell development, $\mathrm{CO}_{2}$ utilization, and contamination prevention. Unwanted changes in the $\mathrm{pH}$ of the cultivation medium disrupt the balance between gaseous $\mathrm{CO}_{2}$ in the medium and other DIC, reduce the availability of nutrients, and impair the photosynthetic and metabolic processes of microalgae, among other things. Spirulina growth is accelerated by the alkaline $\mathrm{pH}$, which results in increased mass transfer of $\mathrm{CO}_{2}$ and high $\mathrm{HCO}_{3}$ ions in the water. Despite this, it is well known that high $\mathrm{CO}_{2}$ levels prevent the accumulation of 
phycobiliprotein and other pigments in the body, such as phycocyanine.

The majority of studies, however, have concentrated on culturing microalgae in fresh water, but considering the wide variation in water quality around the globe, this paper studied the efficiency of various cynobacteria species on $\mathrm{CO}_{2}$ sequestration. The $\mathrm{pH}$ of the culture medium is not controlled in the usual method of microalgae production, which is a disadvantage. In other circumstances, the $\mathrm{pH}$ is maintained through the addition of acid $(\mathrm{HCl})$ or alkali $(\mathrm{NaOH})$, which not only results in an increase in chemical waste but also has the potential to damage the cells themselves. As a result, in this investigation, we attempted to overcome the bottlenecks associated with the use of chemical carbon species by supplementing the culture with gaseous $\mathrm{CO}_{2}$, at the same time optimizing the ideal $\mathrm{pH}$.

\section{MATERIAL AND METHODS}

2.1 Collection of microalgae strain, culture media, and seed culture development for pilot scale raceway pond

The cynobacteria species used in this study were obtained from the National Collection of Industrial Microorganisms (NCIM), in Pune, Maharastra, India. Using a modified Zarrouk's medium, all tested cynobacteria species such as Chlorella sp., Synechococcus sp. and Spirulina sp. were inoculated into a 2L Erlenmeyer flask containing 1L autoclaved media and incubated at room temperature under cool white fluorescent lighting with a light intensity of 27 $\mathrm{E} \mathrm{m}^{-2} \mathrm{~s}^{-1}$ and a photoperiod of 12:12 h light:dark. Zarrouk's medium ( $\mathrm{ZM})$ is the name given to the modified nutritional medium used in the current investigation for the sake of simplicity and data representation in the results. The modified $\mathrm{ZM}$ medium was composed of $\mathrm{NaHCO}_{3}(10 \mathrm{~g}), \mathrm{K}_{2} \mathrm{HPO}_{4}$ $(0.5 \mathrm{~g}), \mathrm{NaNO}_{3}(2.5 \mathrm{~g}), \mathrm{K}_{2} \mathrm{SO}_{4}(1.0 \mathrm{~g}), \mathrm{NaCl}(1.0 \mathrm{~g})$,
$\mathrm{MgSO}_{4} .7 \mathrm{H}_{2} \mathrm{O} \quad(0.2 \quad \mathrm{~g}), \quad \mathrm{CaCl}_{2} .2 \mathrm{H}_{2} \mathrm{O} \quad(0.04 \quad \mathrm{~g})$,

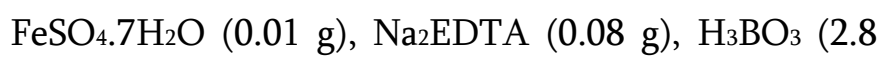
g), $\quad \mathrm{MnCl}_{2} .4 \mathrm{H}_{2} \mathrm{O} \quad(1.8 \mathrm{~g}), \quad \mathrm{ZnSO}_{4.7 \mathrm{H}_{2} \mathrm{O}}(0.2 \mathrm{~g})$, $\mathrm{CuSO}_{4} .5 \mathrm{H}_{2} \mathrm{O} \quad(0.074 \mathrm{~g})$, and $\mathrm{MoO}_{3}(0.015 \mathrm{~g})$. Chemicals, reagents, metal ions, and medium components were acquired from Himedia, Mumbai, India, and were of analytical grade or higher purity available. Moreover, following the exponential growth face of the microalgae and prior to the establishment of the stationary growth phase, the seed culture for experiments was grown consecutively by scaling the culture from $1 \mathrm{~L}$ to $4 \mathrm{~L}$. Further, the cultures were propagated in carboys in order to scale up to a volume of $20 \mathrm{~L}$ at ambient conditions. Additionally, the culture was acclimatized with the addition of pure CO2 (99.99\%) as the sole source of carbon and scaled up to $360 \mathrm{~L}$ using the seed culture development open raceway ponds available at the pilot scale Spirulina cultivation facility, where it was successfully grown to maturity. The optical density (O.D.) of Spirulina at $560 \mathrm{~nm}$ was measured on a regular basis to track its development.

2.2. Design, construction, and operation of a micro algae growing system in a pilot scale open raceway pond

Primary screening of all the tested cunobacteria species were PVC chamber having $28 \mathrm{~cm}$ height, 88 $\mathrm{cm}$ length and $64 \mathrm{~cm}$ width containing a total volume of $10 \mathrm{~L}$ in laboratory conditions. Moreover the screeing of the best cynobacterial species there cultivation was carried out in a 1500L open raceway pond having a working volume of $1500 \mathrm{~L}$ having 700 $\mathrm{cm}$ height, $300 \mathrm{~cm}$ length and $400 \mathrm{~cm}$ width. In the designed pond data logging for $\mathrm{pH}$, temperature, light, dissolved oxygen (DO), and agitation was automatic. Most of the Spirulina cultivators record all these measurements manually which is very laborious and time consuming. The $\mathrm{pH}$, dissolved oxygen (DO), and temperature sensors were immersed in the culture. The key feature of this system is the ability to adjust the $\mathrm{pH}$ of the culture medium by the addition of $\mathrm{CO}_{2}$ 
at varying concentrations and flow rates to the medium. An additional $\mathrm{CO}_{2}$ supply unit, which purges the $\mathrm{CO}_{2}$ based gas on $\mathrm{pH}$ set points, an air mixing system to regulate $\mathrm{CO}_{2}$ concentration, and the management of gas flow rate were included in the system.

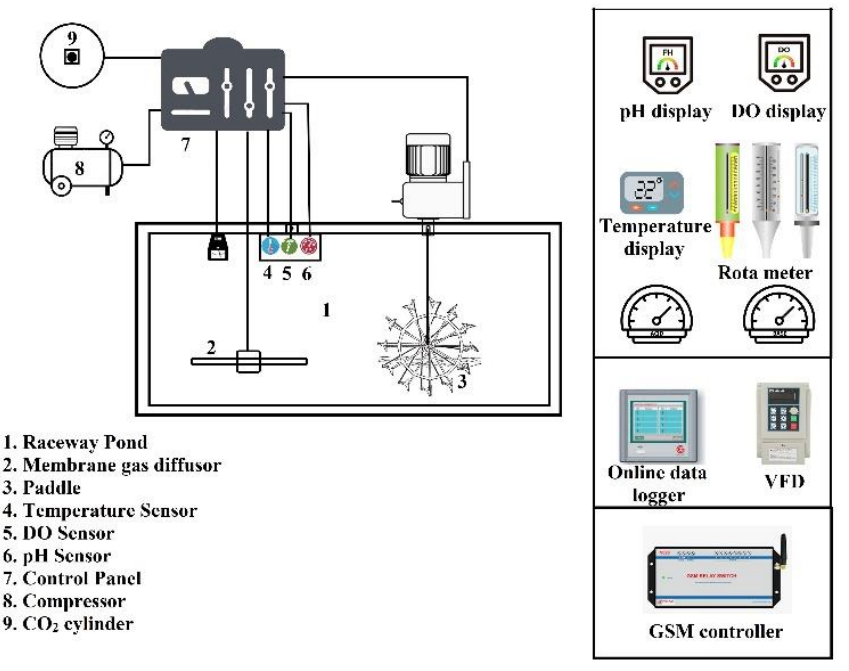

Figure 1: A graphical representation of the 1500 litre open raceway pond, including the control panel and $\mathrm{CO}_{2}$ feeding system.

\subsection{Performance of Spirulina sp. at varied $\mathrm{pH}$ levels in in a $1500 \mathrm{~L}$ open raceway pond}

Effect of various $\mathrm{pH}$ on the overall treatment performance of the Spirulina was determined. The study was conducted in the ambient temperature of the month March to July, 2019. The culture medium used in this study is $\mathrm{ZM}$ except $\mathrm{NaHCO}_{3}$ which was replaced by $\mathrm{CO}_{2}$ as a sole source of carbon. The municipal water supplied for the domestic use was used for the preparation of the culture growth medium to reduce the overall all treatment cost. The acclimatized seed culture prepare in the ambient condition in a small outdoor pond was used as a inoculum. The culture containing optical density of 0.2 at $560 \mathrm{~nm}$ was used as an innoclum in the working volume of the pond $(1500 \mathrm{~L})$. Using pure food grade gaseous $\mathrm{CO} 2$, we were able to regulate and maintain the $\mathrm{pH}$ of the culture at the desired level (either $\mathrm{pH} 7.5,8.5$ or 9.5).
2.4 Cell proliferation, quantification of biomass, and determination of ash content

Cell growth of the Spirulina sp. was determined by calculating the optical density of the culture at 560 $\mathrm{nm}$ by using UV-vis spectrophotometer (Shimadzu, UV-1800). Calculation was done by plotting the standard curve prepared by diluting the Spirulina culture of varying OD verses concentration of cells (mg L L ${ }^{-1}$. Moreover the biomass content was determined by using dry weight procedure. Briefly fixed and same volume of culture suspension was filtered through a pre-weighed glass fibre filters $(0.45$ $\mu \mathrm{m}$ ), and dried in a hot air oven for $12 \mathrm{~h}$ at $60{ }^{\circ} \mathrm{C}$. Further the biomass was gravimetrically calculated based on the change in filters weight, and the dry weight $\left(\mathrm{mg} \mathrm{L}^{-1}\right)$. Whereas, approximately $3 \mathrm{~g}$ of lyophilized Spirulina biomass was dried and corrected for the amount of moisture present in the sample using an automated moisture analyser (Sartorious, MA160) to determine the ash content. Additionally, the total ash content was determined by incinerating the moisture analyzer sample for $6-8$ hours at $525^{\circ} \mathrm{C}$ in a muffle furnace.

\subsection{Harvesting, lyophilisation, and storage of biomass}

The filtration process was used for the harvesting of the culture after the completion of the a pilot scale raceway pond. Primarily $1 \mathrm{~mm}$ sieve was used to remove the debris and external products from the culture. After that the pre-filtered microalgae culture was filtered through a $100 \mu \mathrm{m}$ mesh size nylon cloth to obtain a wet biomass. Further to remove the salt from the collected biomass they were washed with 1 $\mathrm{N} \mathrm{HCl}$. Further, for $24 \mathrm{~h}$ the harvested biomass was freeze-dried using a vacuumed lyophilizer. The dried and powdered culture biomass was also kept at $4^{\circ} \mathrm{C}$ before being used in the subsequent analysis. 
2.6 Determination of productivity of biomass, proteins, carbohydrates, lipids, and phycocyanine

\subsubsection{Biomass productivity}

The biomass productivity of the microalgae was determined by measuring the change in the biomass by following the below mentioned formula:

$\mathrm{P}=\mathrm{B}_{\mathrm{t}}-\mathrm{B}_{0} /\left(\mathrm{t}-\mathrm{t}_{0}\right)$

The starting biomass concentration at time to is represented by $\mathrm{B}_{0}$, whereas the biomass concentration at any time $t$ is represented by $\mathrm{B}_{\mathrm{t}}$.

\subsubsection{Estimation of total protein}

Total nitrogen content was estimated using the protein analyser (Thermo Flash 2000) on the lyophilized biomass $(30 \mathrm{mg})$. The following formula was used to calculate the biomass's total protein content:

Total protein $(\%)=$ Total nitrogen $(\%) \times 6.25$

\subsubsection{Estimation of total carbohydrate}

The phenol sulfuric acid technique using glucose as a reference was used to assess the total carbohydrate content. Dried biomass (w/v) was dissolved in boiling water for 20 minutes and digested with $5 \mathrm{ml}$ of $2.5 \mathrm{M}$ hydrochloric acid $(\mathrm{HCl})$. To eliminate effervescence and get final quantification data, the hydrolyzed biomass was chilled, neutralised with anhydrous $\mathrm{Na}_{2} \mathrm{CO}_{3}$, and diluted $(10 \mathrm{ml})$. The developed colour was measured at $490 \mathrm{~nm}$ after adding $1 \mathrm{ml}$ of $5 \%$ phenol and $5 \mathrm{ml}$ of $96 \% \mathrm{H}_{2} \mathrm{SO}_{4}$ to the diluted solution $(0.2-1.0 \mathrm{ml})$.

\subsubsection{Estimation of total lipids}

The lyophilized cynobacteria biomass (100 mg) was dissolved in a 10:10:9 mixture of chloroform, methanol, and water. The samples were then vortexed and shaken overnight before being centrifuged at $5000 \mathrm{~g}$ for 5 minutes. Further, the bottommost layer of chloroform containing the lipids was removed using a pre-sterile $0.2 \mathrm{~m}$ syringe filter in a pre-weighed glass vial (W1). The chloroform was then evaporated, and the glass vials were re-weighed (W2). The difference in weight of the glass vials (W3 = W2 W1) was used to compute the \% lipid content when the quantity of biomass utilized for extraction was taken into account.

\subsubsection{Estimation of phycocyanin}

To quantify crude phycocyanin (Cp), $20 \mathrm{mg}$ of lyophilised biomass was mixed with $20 \mathrm{ml}$ of $100 \mathrm{mM}$ phosphate buffer (w/v) at $\mathrm{pH} 7$. It was then well blended and refrigerated overnight at $4{ }^{\circ} \mathrm{C}$. The sample was centrifuged the next day, and the absorbance of a supernatant was measured at $615 \mathrm{~nm}$ and $652 \mathrm{~nm}$. The phycocyanin extract was quantified using Bennett and Bogorad's equation, which is as follows:

$\mathrm{Cp}=\mathrm{A}_{615}-\left(0.474 \times \mathrm{A}_{652}\right) / 5.34$

Where; $\mathrm{Cp}=$ Crude phycocyanin concentration (g

$\mathrm{L}^{-1}$ ); A615=Absorbance of the extract at $615 \mathrm{~nm}$; and $A_{652}=$ Absorbance of the extract at $652 \mathrm{~nm}$.

\subsection{Elemental composition ( $\mathrm{C}, \mathrm{H}, \mathrm{N}, \mathrm{S}$ and $\mathrm{O}$ content) analysis of biomass}

With the use of a CHNSO analyser (ELIII, Vario, Germany), the lyophilised biomass was weighed in the range of 5-10 $\mathrm{mg}$ and examined for the measurement of the carbon $(\mathrm{C})$, hydrogen $(\mathrm{H})$, nitrogen $(\mathrm{N})$, and sulphur $(\mathrm{S})$ contents, among other things.

\subsection{Analysis of carbon dioxide ( $\mathrm{CO} 2)$ bio-fixation rate}

The following equation was used to compute the rate of inorganic carbon (IC) use (as equivalent $\mathrm{CO} 2$ biofixation) $\mathrm{RCO}_{2}\left(\mathrm{~g} \mathrm{~L}^{-1} \mathrm{~d}^{-1}\right)$.

$\mathrm{R}_{\mathrm{CO} 2}=\mathrm{C}_{\mathrm{c}} \mathrm{P}\left(\mathrm{M}_{\mathrm{cO} 2} / \mathrm{M}_{\mathrm{c}}\right)$

Where $\mathrm{C}_{c}$ represents the carbon content (\% dry cell weight) of cynobacteria biomass and $\mathrm{P}$ represents biomass production. $\mathrm{M}_{\mathrm{c}}$ and $\mathrm{M}_{\mathrm{co} 2}$ where, the molecular weights of $\mathrm{CO}_{2}$ and carbon, respectively. 


\subsection{Determination of alkalinity, $\mathrm{NO}_{3}{ }^{-}$and $\mathrm{PO}_{4}{ }^{2-}$}

Representative samples of culture media were collected and centrifuged at $5000 \mathrm{rpm}$ for 10 minutes, biomass was discarded and supernatant was used to analyze the concentrations of alkalinity, $\mathrm{NO}_{3}{ }^{-}$and $\mathrm{PO}_{4}{ }^{2-}$. The alkalinity was measured by following the titrimetric method by following the procedure described by Cheng et al. (2018). It was necessary to monitor the alkalinity of the culture medium on a daily basis in order to calculate the concentration of dissolved inorganic carbon ( $\mathrm{HCO}^{-}$and $\mathrm{CO}_{3}{ }^{-}$). The concentrations of $\mathrm{NO}_{3}{ }^{-}$and $\mathrm{PO}_{4}^{-}$in the cynobacteria species were measured on a daily basis during the cultivation period. The amount of $\mathrm{NO}_{3}{ }^{-}-\mathrm{N}$ in the water was estimated by measuring the absorbance at $220 \mathrm{~nm}$ and $275 \mathrm{~nm}$ using an ultraviolet-visible spectrometer. The Vanadomolybdophosphoric acid colorimetric technique was used to quantify the content of $\mathrm{PO}_{4}{ }^{2--} \mathrm{P}$ in the sample.

\subsection{Characterization of wastewater}

Chemical oxygen demand (COD), biochemical oxygen demand (BOD), total solids (TS), $\mathrm{pH}$, phenols, total dissolved solids (TDS), sulphate, nitrate, alkalinity, acidity, total hardness, and the presence of heavy metals were used to characterise the wastewater. The $\mathrm{pH}$ value was determined using a digital $\mathrm{pH}$ metre (ANALAB, India). BOD was determined using a $\mathrm{DO}$ metre $(\mathrm{HACH}, \mathrm{DO} 6)$. The COD value was determined using a HACH DRB200 thermoreactor and a HACH DR6000 spectrophotometer. Metals were detected using a Perkin Elmer Optima 3300 RL ICP-OES (Inductive Coupled Plasma-Optical Emission Spectrometer). All other parameters were determined in accordance with APHA 2005.

\section{RESULTS AND DISCUSSION}

\subsection{Screening of cynobacteria species for $\mathrm{CO}_{2}$ bio- sequestration}

Initially in this study, three distinct cynobacteria species, including Spirulina sp., Chlorella sp., and Synechococcus sp., were primarily tested for their capacity to bio-sequester $\mathrm{CO}_{2}$ in 10 litre raceway ponds. The biomass productivity, growth rate, and $\mathrm{CO}_{2}$ sequestration rate of each cynobacteria species were determined at varying levels of $\mathrm{CO}_{2}$ and $\mathrm{EC}$. The effect of various $\mathrm{CO}_{2}$ concentrations $(0.02 \%, 2 \%, 5 \%$, and $10 \%$ ) on the growth of each tested cynobacteria species is depicted in Fig.1. It has been widely documented in the published literature that microalgae are more effective at carbon sequestration, although each examined cynobacteria species is efficient at growing at elevated $\mathrm{CO}_{2}$ concentrations. Additionally, it was previously reported that when $\mathrm{CO}_{2}$ concentrations were increased, microalgae cells grew more efficiently, and their organelles containing chlorophyll $\mathrm{a}$ and $\mathrm{b}$ made them very effective at photosynthetic activities that result in the conversion of $\mathrm{CO}_{2}$ to $\mathrm{O}_{2}$ (Singh and Singh, 2014). As shown in the Fig. 1 all three tested cynobacteria species were efficient grown in the $\mathrm{CO}_{2}$ concentration of 5 and 10\%. Similarly, Shabani et al. (2016) observed that Spirulina platensis and Chlorella vulgaris grew at their highest rates at $\mathrm{CO}_{2}$ concentrations ranging from 0.03 to $10 \%$. In another study Tang et al. (2011) observed the highest growth rate of Scenedesmus obliquus and Chlorella pyrenoidosa at $\mathrm{CO}_{2}$ concentrations ranging from $5 \%$ to $30 \%$. Upendar et al. (2017) evaluated the effacement of Synechococcus sp. NIT18 for $\mathrm{CO}_{2}$ sequestration and also reported a high biomass of the tested cynobacteria at elevated $\mathrm{CO}_{2}$ concentrations (5-20\%).

(a)

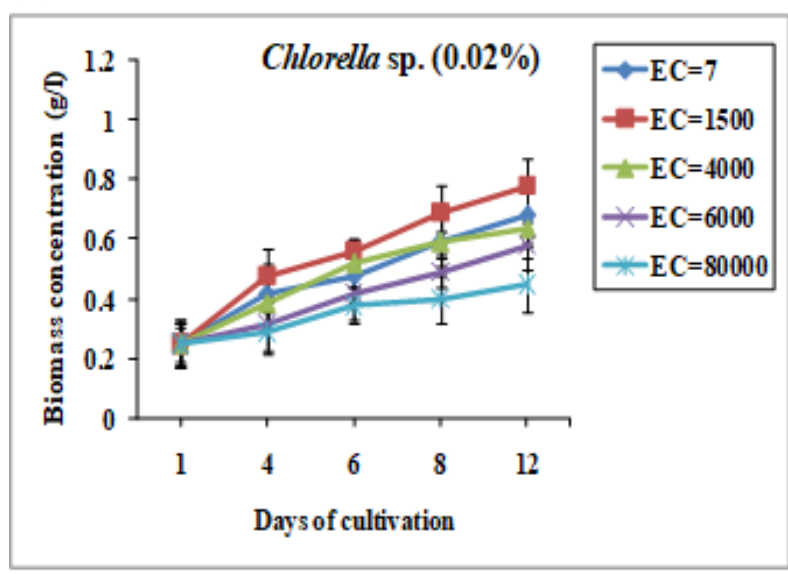


(b)

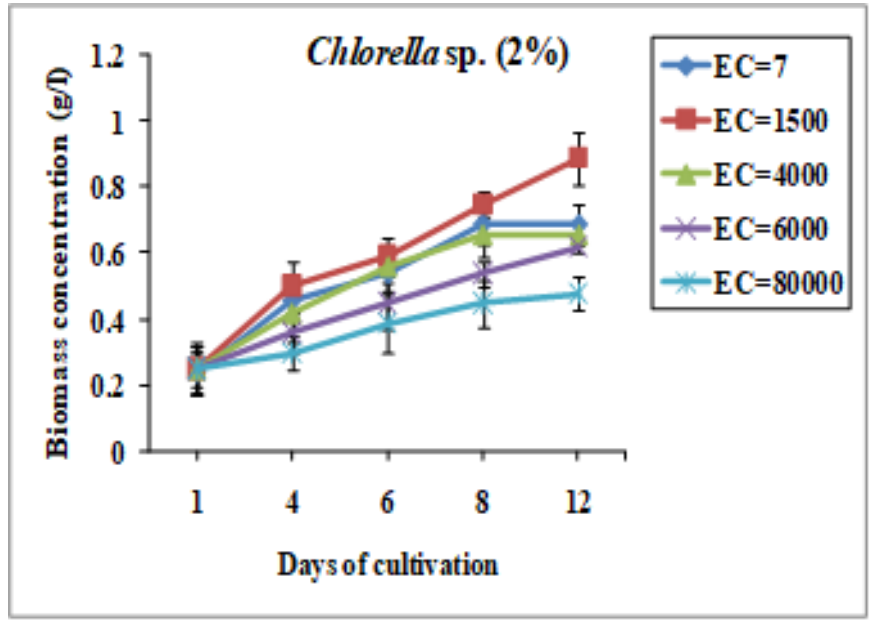

(c)

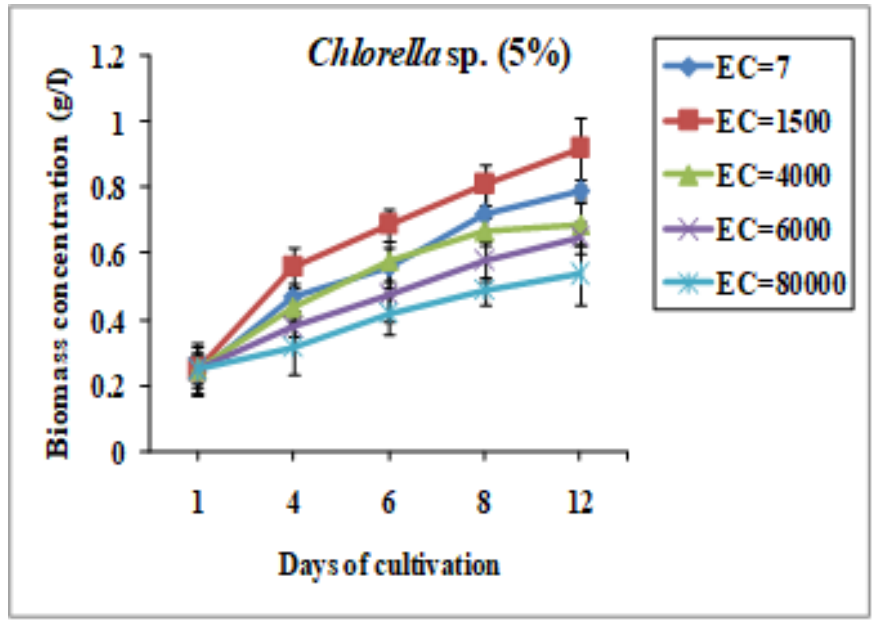

(d)

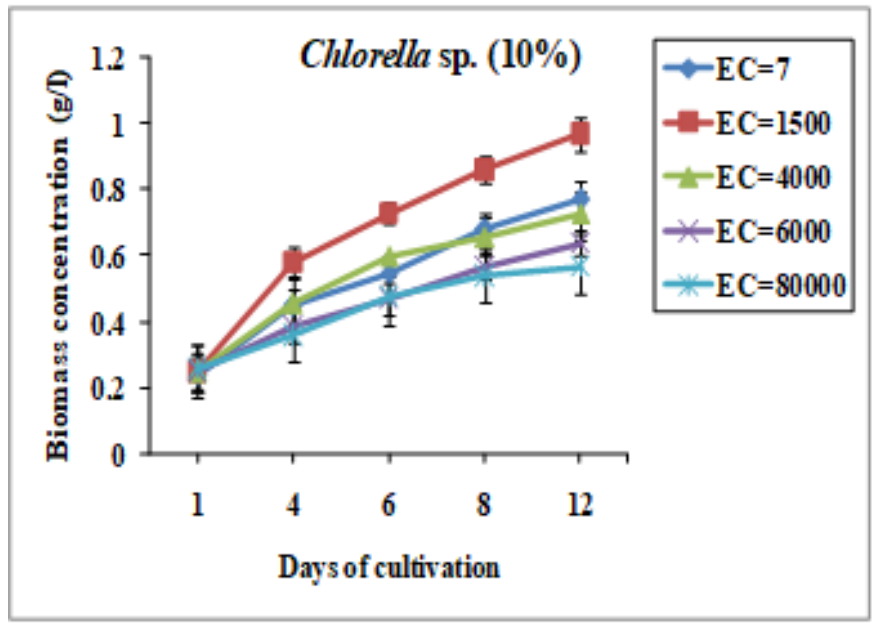

(e)

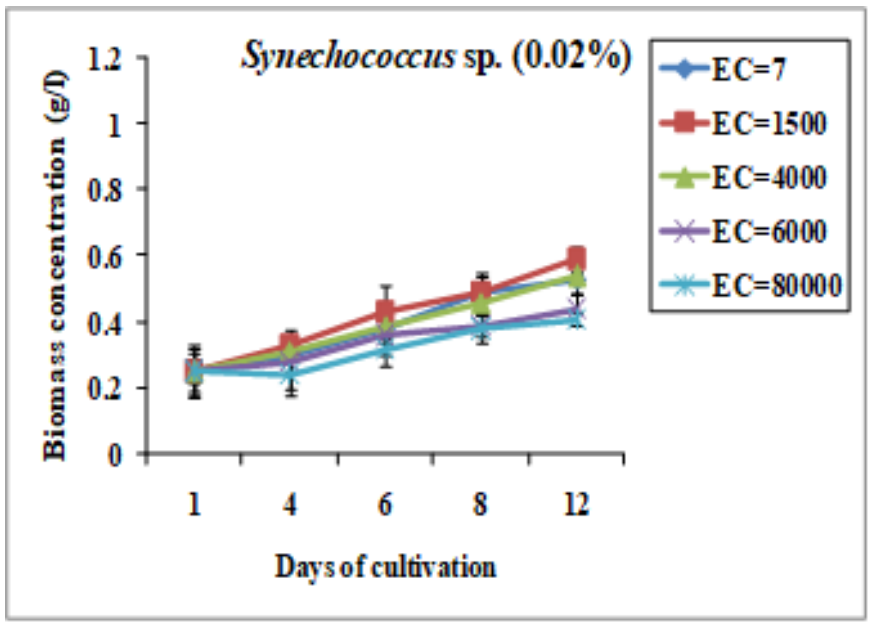

(f)

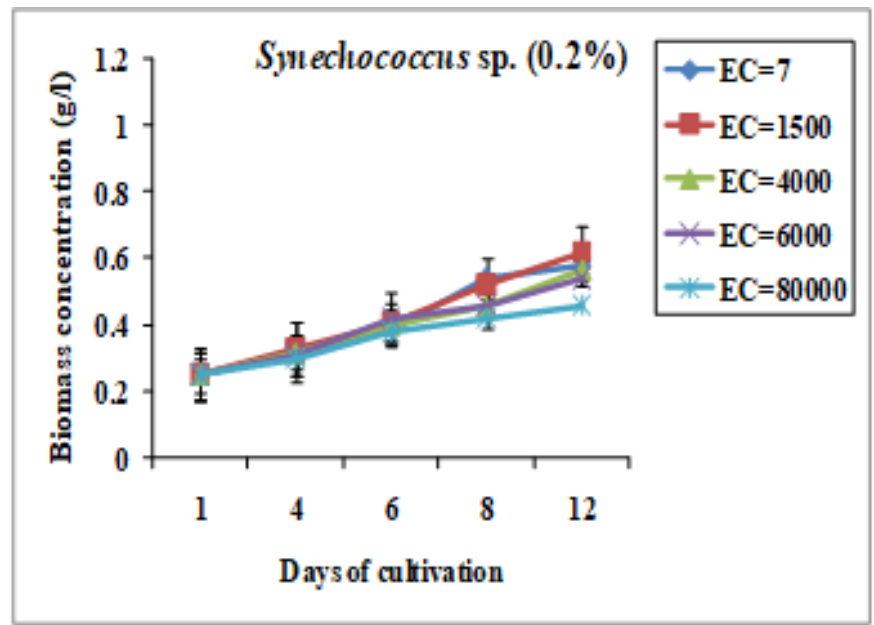

(g)

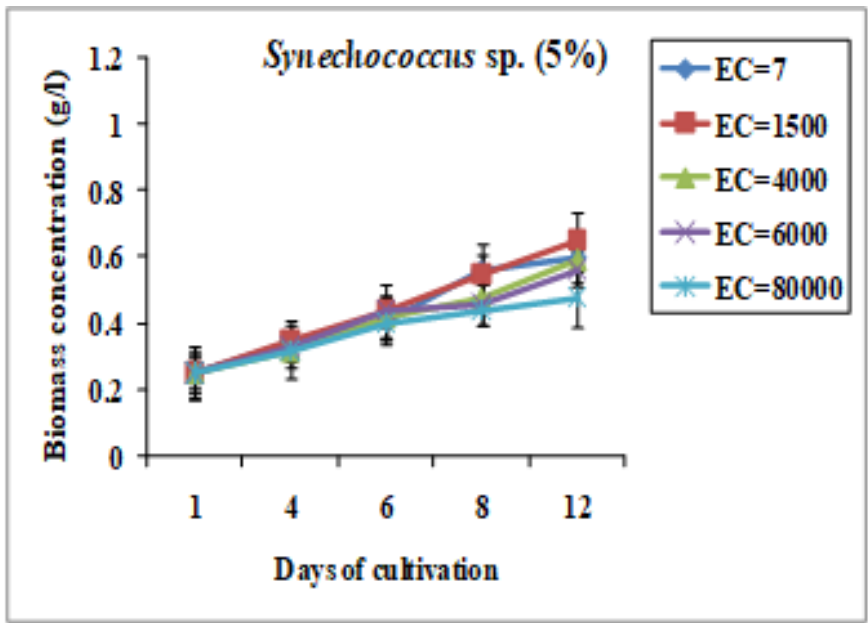


(h)

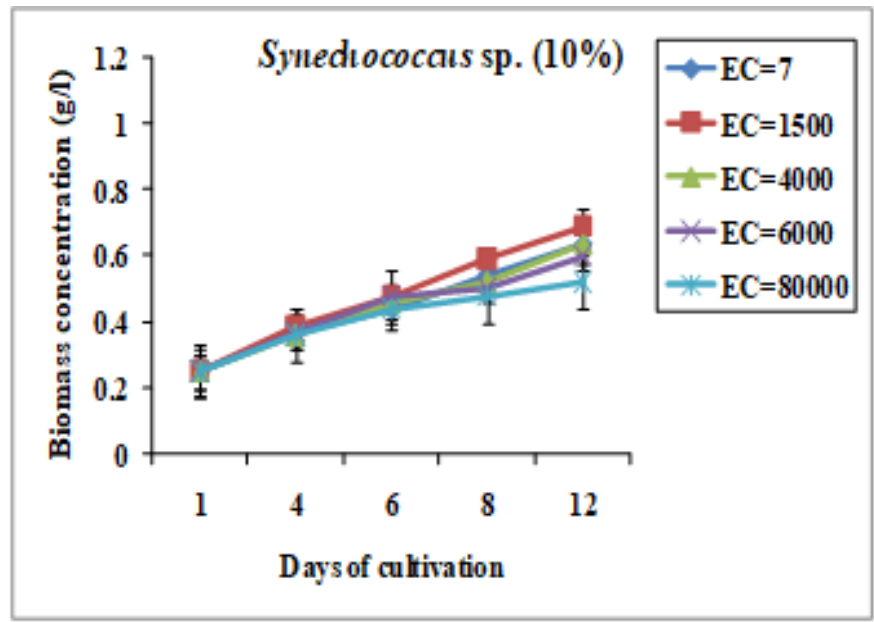

(i)

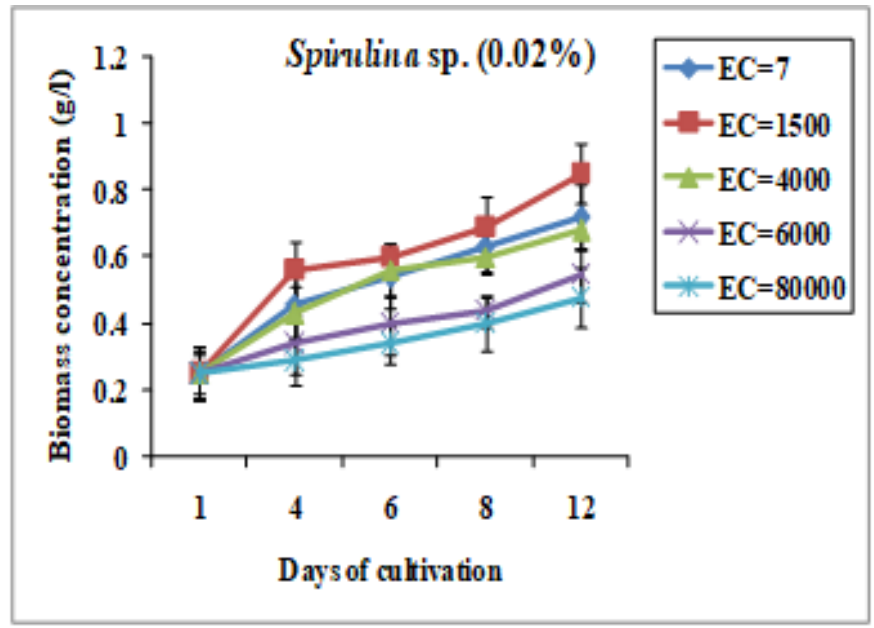

(j)

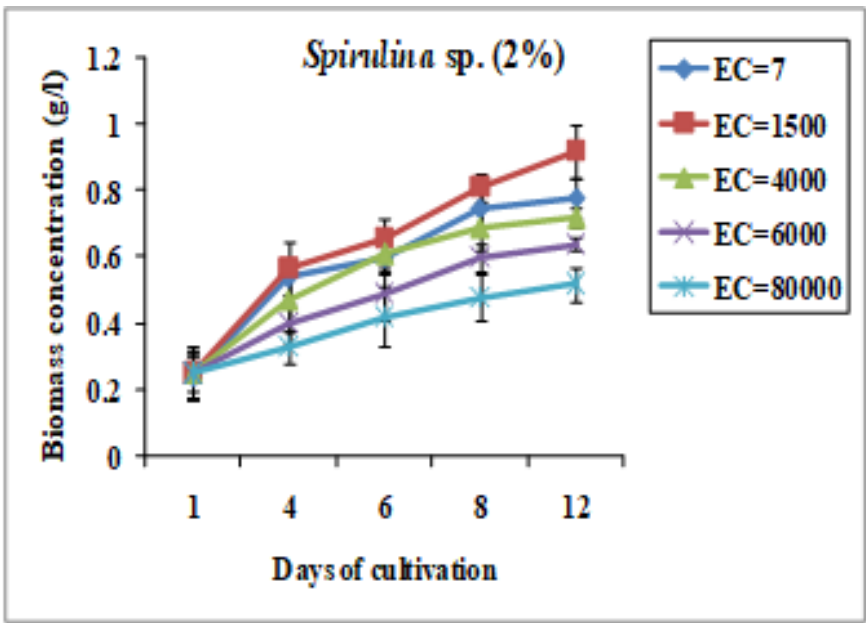

(k)

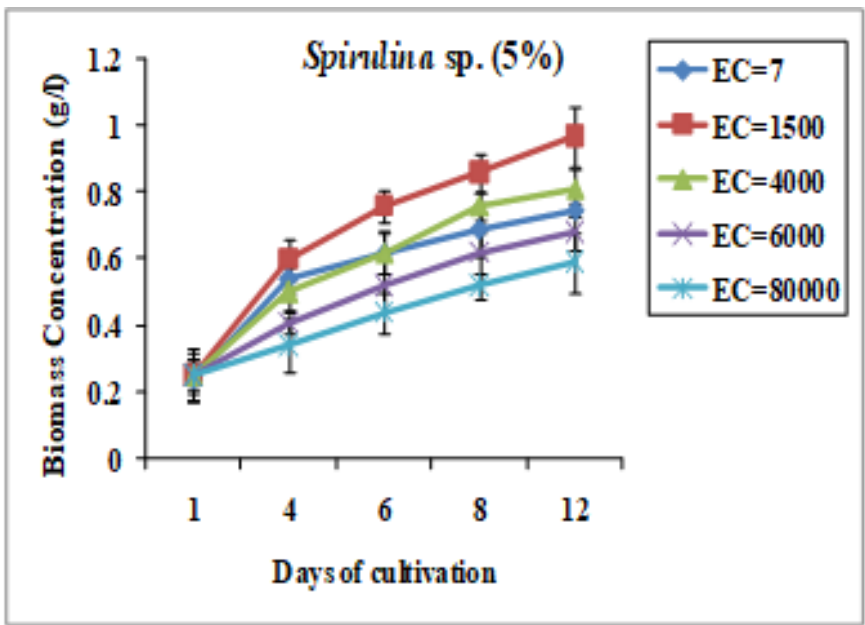

(1)

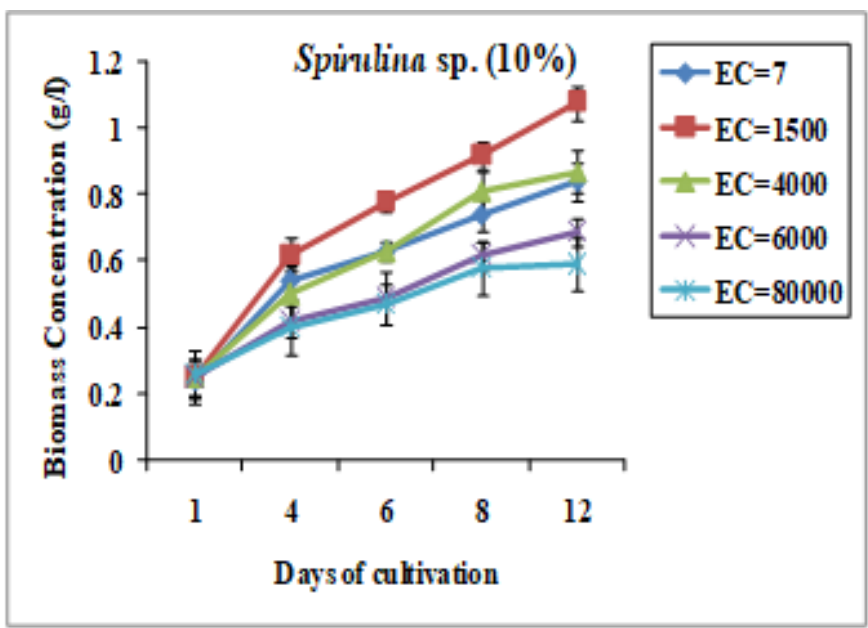

Figure 2 : Biomass production of Chlorella sp., Synechococcus sp. and Spirulina sp. under various CO2 concentration and EC in 10 litre PVC raceway ponds.

As illustrated in Fig. 1, a significant increase in the growth rate of all tested cynobacteria species was observed after the initial four days of cultivation at EC 1500, moreover after that time period of cultivation the growth rate was increased subsequently. Chlorella sp. produced 0.78, 0.89, 0.92, and $0.97 \mathrm{~g} / \mathrm{l}$ of biomass in the presence of $\mathrm{CO}_{2}$ concentrations of $0.02,2,5$, and $10 \%$, respectively, in four different experiments. Whereas Synechococcus sp. showed $0.59,0.62,0.65$ and $0.69 \mathrm{~g} / \mathrm{l}$ of biomass production in the presence of $\mathrm{CO}_{2}$ concentrations of $0.02,2,5$, and $10 \%$, respectively. While as compared to Chlorella sp. and Synechococcus sp., Spirulina sp. showed highest biomass production of $0.85,0.92,0.97$, 
and $1.08 \mathrm{~g} / \mathrm{l}$ in the presence of $\mathrm{CO}_{2}$ concentrations of $0.02,2,5$, and $10 \%$, respectively. This indicated that among all tested cynobacteria species Spirulina sp. was the best cynobacteria for the growth and $\mathrm{CO}_{2}$ bio-sequestration which was further used in large scale raceway pond.

\subsection{Wastewater treatment efficiency of screened cynobacteria species}

The removal of COD, BOD, and other wastewater parameters such as alkalinity, acidity, and metal ions is considered to be the primary indicator of a microrganism's treatment efficiency. Following the results shown in Table 1, all three of the examined cynobacteria species are effective in the treatment of wastewater collected from the discharge point of the CETP treated effluent into the sabarmati river.

\begin{tabular}{|l|l|l|l|l|}
\hline $\begin{array}{l}\text { Parameters } \\
(\mathrm{mg} / \mathrm{L})\end{array}$ & $\begin{array}{l}\text { Wastew } \\
\text { ater }\end{array}$ & $\begin{array}{l}\text { Chlor } \\
\text { ella } \\
\text { sp. } \\
\text { treat } \\
\text { ment }\end{array}$ & $\begin{array}{l}\text { Synec } \\
\text { hococc } \\
\text { us sp. } \\
\text { treatm } \\
\text { ent }\end{array}$ & $\begin{array}{l}\text { Spiruli } \\
\text { na sp. } \\
\text { teratme } \\
\text { nt }\end{array}$ \\
\hline COD & $810 \pm 11$ & $\begin{array}{l}356 \pm 1 \\
5\end{array}$ & $\begin{array}{l}417 \pm 1 \\
2\end{array}$ & $185 \pm 17$ \\
\hline BOD & $431 \pm 8$ & $221 \pm 7$ & $\begin{array}{l}298 \pm 1 \\
8\end{array}$ & $204 \pm 3$ \\
\hline TSS & $46 \pm 4$ & $28 \pm 4$ & $32 \pm 6$ & $17 \pm 2$ \\
\hline TDS & $54 \pm 6$ & $30 \pm 4$ & $38 \pm 2$ & $18 \pm 1$ \\
\hline Phenols & $68 \pm 14$ & $38 \pm 6$ & $43 \pm 5$ & $23 \pm 4$ \\
\hline Sulphate & $63 \pm 3$ & $27 \pm 4$ & $38 \pm 7$ & $15 \pm 2$ \\
\hline Nitrate & $21 \pm 3$ & $10 \pm 1$ & $17 \pm 3$ & N.D. \\
\hline Alkalinity & $13 \pm 4$ & $6 \pm 2$ & $9 \pm 1$ & N.D. \\
\hline Acidity & $62 \pm 9$ & $18 \pm 6$ & $41 \pm 4$ & N.D. \\
\hline $\begin{array}{l}\text { Total } \\
\text { hardness }\end{array}$ & $38 \pm 3$ & $27 \pm 5$ & $23 \pm 3$ & $14 \pm 3$ \\
\hline Iron & 6.32 & N.D. & 2.84 & N.D. \\
\hline Copper & 4.86 & N.D. & 1.42 & N.D. \\
\hline Zinc & 5.6 & N.D. & 2.18 & N.D. \\
\hline Barium & 3.6 & N.D. & N.D. & N.D. \\
\hline $\begin{array}{l}\text { Chromium } \\
\text { (VI) }\end{array}$ & 44.6 & 11.8 & 24.6 & 4.9 \\
\hline Cobalt & 32.4 & 24.3 & 28.8 & 18.4 \\
\hline N.D. Not detected & & & \\
\hline
\end{tabular}

N.D. = Not detected
Table 1: Characterization of treated and untreated wastewater by tested cynobacteria species.

The $\mathrm{BOD}_{5} \mathrm{COD}$ ratio is the primary indicator of a water's biodegradable nature. It was previously reported that $\mathrm{BOD}_{5} \mathrm{COD}$ ratios less than 0.1 were considered non-biodegradable, while $\mathrm{BOD}_{5}$ :COD ratios greater than 0.5 were considered biodegradable (Azbar et al., 2004; Han et al., 2015). The BODs:COD ratio of the wastewater used for cynobacterial screening was 0.53 , indicating that the water is readily biodegradable. After treatment of wastewater with Chlorella sp., Synechococcus sp., and Spirulina sp., the BOD5: COD ratio increased to $0.62,0.71$, and 1.10 , respectively, indicating that all of these tested cyanobacteria species are not only treating the wastewater but also simultaneously increasing the BOD 5 : COD ratio of the water, resulting in complete mineralization of the organic compounds present in the wastewater after its discharge into natural ecosystem. Moreover, Chlorella sp., Synechococcus sp., and Spirulina sp., were also found to be efficient in the COD removal of the wastewater. The Chlorella sp. showed 56\% COD removal, Synechococcus sp. showed 48\% COD removal and Spirulina sp. showed the maxium COD removal of $77 \%$. Additionally the BOD removal was found tobe $48 \%, 30 \%$ and $52 \%$ by Chlorella sp., Synechococcus sp., and Spirulina sp. respectively.

\subsection{Effect of temperature on the growth of Chlorella} sp., Synechococcus sp., and Spirulina sp.

After 10 days of cultivation, the effect of temperature was determined at optimum EC and $10 \% \quad \mathrm{CO}_{2}$ concentration. According to the results, all of the tested cynobacteria species grew efficiently at temperatures ranging from 30 to $35^{\circ} \mathrm{C}$. 


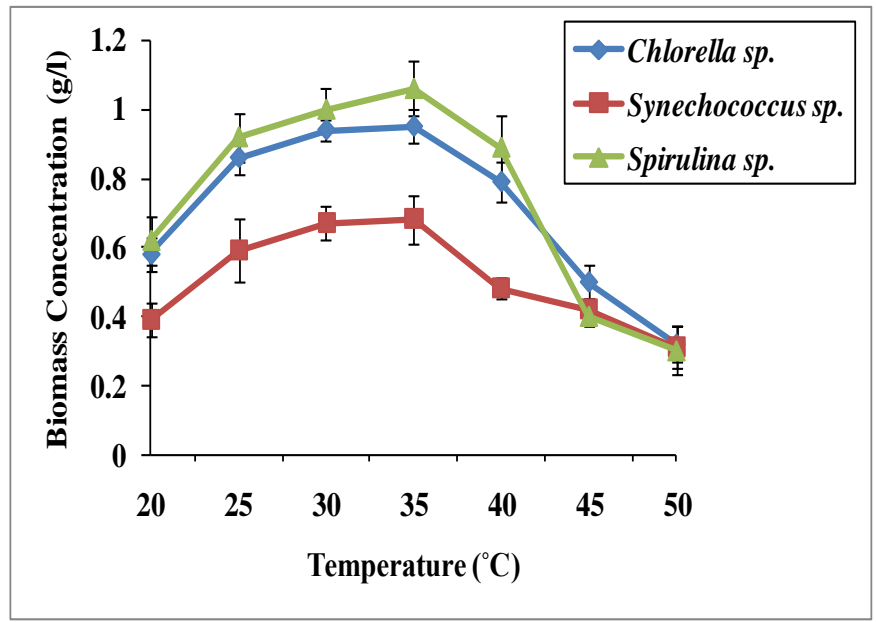

Figure 3: Biomass production of Chlorella sp., Synechococcus sp. and Spirulina sp. at various temperatures.

Chlorella sp. produced the maximum biomass $(0.95$ $\mathrm{g} / \mathrm{l})$ at $35^{\circ} \mathrm{C}$, while Synechococcus sp. produced the maximum biomass $(0.68 \mathrm{~g} / \mathrm{l})$ at $35^{\circ} \mathrm{C}$. Additionally, when compared to Chlorella sp. and Synechococcus sp., Spirulina sp. showed the maximum biomass production $(1.06 \mathrm{~g} / \mathrm{l})$ at $35^{\circ} \mathrm{C}$. These findings suggest that Spirulina sp. can be used for bio-sequestration at ambient temperature. Previously similar results were observed by Oliveira et al. (1999) authors observed the maximum growth of S. maxima and S. platensis between the temperature 25 to $35^{\circ} \mathrm{C}$.

\subsection{Effect of $\mathrm{pH}$ variations induced by $\mathrm{CO}_{2}$ feeding on the production of Spirulina sp. biomass in a 1500 litre raceway pond}

It has previously been shown in the literature that the $\mathrm{pH}$ of the culture medium has a significant impact on the growth and cell behaviour of microalgae throughout the cultivation period (Mehar et al., 2019). The scarcity of knowledge on the intake and secretion of chemical species has clouded our understanding of the stoichiometry of algae's photosynthetic growth (Scherholz et al., 2013). As a result, it is difficult to attain high Spirulina growth rates, which would increase biomass productivity and economic viability of commercial systems such as open raceway ponds. .
As shown in Table 2, Spirulina sp. was capable of growing at all four $\mathrm{pH}$ values tested, including $\mathrm{pH} 7,8$, 9 , and 10 . The production of biomass was determined to be between 46 and $73 \mathrm{mg} / \mathrm{l} / \mathrm{d}$.

Table 2: Biomass production (mg/l/d) of Spirulina sp. in 1500 litre raceway pond, carbon content (\%) and $\mathrm{CO}_{2}$ bio-fixation rate $(\mathrm{g} / \mathrm{l} / \mathrm{d})$ after 10 days of cultivation

\begin{tabular}{|c|c|c|c|}
\hline $\begin{array}{l}\text { Cultivation } \\
\text { conditions }\end{array}$ & $\begin{array}{l}\text { Biomass } \\
\text { production } \\
(\mathrm{mg} / \mathrm{l} / \mathrm{d})\end{array}$ & $\begin{array}{l}\text { Carbon } \\
\text { content } \\
(\%)\end{array}$ & $\begin{array}{l}\mathrm{CO}_{2} \\
\text { bio- } \\
\text { fixation } \\
\text { rate } \\
(\mathrm{g} / \mathrm{l} / \mathrm{d})\end{array}$ \\
\hline $\begin{array}{l}\mathrm{pH} 7 \pm 0.1 \\
\left(+\mathrm{CO}_{2}\right)\end{array}$ & $46 \pm 2.85$ & $\begin{array}{l}41 \pm \\
0.25\end{array}$ & $\begin{array}{l}0.08 \pm \\
0.02\end{array}$ \\
\hline $\begin{array}{l}\mathrm{pH} 8 \pm 0.1 \\
\left(+\mathrm{CO}_{2}\right)\end{array}$ & $68 \pm 3.75$ & $\begin{array}{l}52 \pm \\
0.41\end{array}$ & $\begin{array}{l}0.13 \pm \\
0.03\end{array}$ \\
\hline $\begin{array}{l}\mathrm{pH} 9 \pm 0.1 \\
\left(+\mathrm{CO}_{2}\right)\end{array}$ & $59 \pm 4.52$ & $\begin{array}{l}50 \pm \\
0.63\end{array}$ & $\begin{array}{l}0.11 \pm \\
0.04\end{array}$ \\
\hline $\begin{array}{l}\mathrm{pH} 10 \pm 0.1 \\
\left(+\mathrm{CO}_{2}\right)\end{array}$ & $48 \pm 4.21$ & $\begin{array}{l}48 \pm \\
0.79\end{array}$ & $\begin{array}{l}0.12 \pm \\
0.02\end{array}$ \\
\hline $\begin{array}{l}\mathrm{ZM}\left(-\mathrm{CO}_{2} ; \mathrm{No}\right. \\
\mathrm{pH} \text { control })\end{array}$ & $73 \pm 3.66$ & $\begin{array}{l}51 \pm \\
0.82\end{array}$ & $\begin{array}{l}0.14 \pm \\
0.01\end{array}$ \\
\hline $\begin{array}{l}\mathrm{ZM}\left(+\mathrm{CO}_{2} ; \mathrm{No}\right. \\
\mathrm{pH} \text { control })\end{array}$ & $67 \pm 2.28$ & $\begin{array}{l}46 \pm \\
0.47\end{array}$ & $\begin{array}{l}0.10 \pm \\
0.02\end{array}$ \\
\hline
\end{tabular}

Furthermore, the biomass production of Spirulina sp. at different $\mathrm{CO}_{2}$ levels and $\mathrm{pH}$ levels was compared to the ZM medium with and without $\mathrm{CO}_{2}$ supplementation and $\mathrm{pH}$ control. The highest biomass production was recorded at $\mathrm{pH} 8(683.75 \mathrm{mg} / \mathrm{l} / \mathrm{d})$, which was $20 \mathrm{mg} / \mathrm{l} / \mathrm{d}$ more than $\mathrm{pH} 10$ but less by 5 $\mathrm{mg} / \mathrm{l} / \mathrm{d}$ in $\mathrm{ZM}$. Variable biomass productivities at various $\mathrm{pH}$ levels may be related to the fact that variations in medium $\mathrm{pH}$ are known to affect the ionisation of nutritional molecules and chemical 
species, potentially limiting their intracellular availability. Moreover, the high $\mathrm{CO}_{2}$ biosequestration rate was observed at $\mathrm{pH} 8$.

\subsection{Determination of Protein, carbohydrate, lipid, phycocyanin content of Spirulina sp. biomass}

Figure 4 depicts the protein, carbohydrate, lipid, and phycocyanin composition of Spirulina sp. biomass.

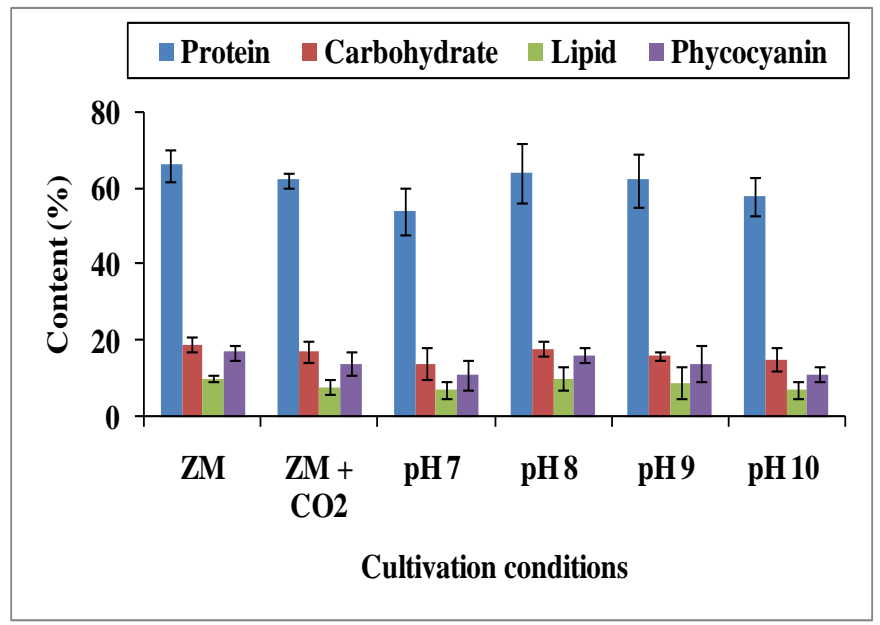

Figure 4: Protein, lipid, carbohydrate, and phycocyanin concentrations under varied culture conditions.

It has previously been observed that environmental conditions, as well as $\mathrm{pH}$ change, have a significant impact on the generation of microalgae biomass. In order to adapt to the environmental circumstances, microalgae store their chemical energy in the form of carbohydrates, lipids, and proteins. Moreover Spirulina was reported to contain $40-70 \%$ high quality protein, including all necessary amino acids. Spirulina sp. biomass had a total protein content of 54-66 \% under all cultivation conditions. The highest protein content (66\%) was observed under standard culture conditions in ZM medium which was very close to the total protein content observed at $\mathrm{pH} 8$ (64). Among all tested $\mathrm{pH}$ conditions Spirulina sp. showed the maximum total protein concentration at $\mathrm{pH}$ 8. At different $\mathrm{pH}$ levels, a similar pattern was seen in the increase of total carbohydrate-like protein in biomass. The total carbohydrate content varied between $14-19 \%$, with a maximum of $18 \%$ at $\mathrm{pH} 8$ and $16 \%$ at $\mathrm{pH} 9$. This was almost identical to the carbohydrate concentration seen in the presence of ZM medium (19\%). The total lipid content was comparable at $\mathrm{pH} 8$ and under conventional culture conditions (with ZM). Additionally, it was revealed that the other three $\mathrm{pH}$ conditions accumulated $7 \%$ ( $\mathrm{pH} 7$ ), 9\% (pH 9) and 7\% (pH 10) of lipid. Because of the presence of gamma-linoleic acid in Spirulina's lipids, these lipids have been shown to have high nutraceutical value. Most significantly, Spirulina is extensively farmed for the production of Cphycocyanin (C-PC), a pigment that plays a critical role as a light harvesting pigment, exhibits a variety of bioactive properties, and has a significant economic value in the nutraceutical and pharmaceutical industries. The total C-PC content at various $\mathrm{pH}$ conditions had varied between $11-17 \%$, with a maximum of $16 \%$ at $\mathrm{pH} 8$ and $14 \%$ at $\mathrm{pH}$ 9. This was almost identical to the carbohydrate concentration seen in the presence of ZM medium (17\%).

\section{CONCLUSIONS}

In areas with insufficient fresh water resources, such as dry and semi-arid regions, where plant growth is likewise constrained by a lack of available water, growing algae is one of the best proposed options. In comparison to Chlorella sp. and Synechococcus sp., Spirulina sp. was shown to be more effective in producing biomass and sequestering $\mathrm{CO}_{2}$. Additionally, Spirulina sp. was shown to have a greater capacity for bioremediation than Chlorella sp. and Synechococcus sp. The maximum biomass production of Spirulina sp. was observed at $35-37{ }^{\circ} \mathrm{C}$, suggesting that the tested cynobacterial species were suitable for use at ambient temperature in open environment. Specifically, the objective of this study is to better understand the behaviour and capabilities of tested cynobacterial cultures at varied $\mathrm{pH}$ levels that are maintained by $\mathrm{CO}_{2}$ feeding. Using an open raceway pond with a capacity of 1500 Litre, we 
successfully designed, manufactured, installed, and operated a pilot scale system for Spirulina cultivation at ambient conditions.

\section{REFERENCES}

[1]. Lowe, J. A., Huntingford, C., Raper, S. C. B., Jones, C. D., Liddicoat, S. K., \& Gohar, L. K. (2009). How difficult is it to recover from dangerous levels of global warming? Environmental Research Letters, 4(1), 014012.

[2]. Solomon, S., Manning, M., Marquis, M., \& Qin, D. (2007). Climate change 2007-the physical science basis: Working group I contribution to the fourth assessment report of the IPCC (Vol. 4). Cambridge university press.

[3]. Gough, C. (2008). State of the art in carbon dioxide capture and storage in the UK: An experts' review. International Journal of Greenhouse Gas Control, 2(1), 155-168.

[4]. Cao, L., \& Caldeira, K. (2010). Atmospheric carbon dioxide removal: long-term consequences and commitment. Environmental Research Letters, 5(2), 024011.

[5]. Ono, E., \& Cuello, J. L. (2006). Feasibility assessment of microalgal carbon dioxide sequestration technology with photobioreactor and solar collector. Biosystems engineering, 95(4), 597-606.

[6]. Chang, E. H., \& Yang, S. S. (2003). Some characteristics of microalgae isolated in Taiwan for biofixation of carbon dioxide. Botanical Bulletin of Academia Sinica, 44.

[7]. Fan, L. H., Zhang, Y. T., Cheng, L. H., Zhang, L., Tang, D. S., \& Chen, H. L. (2007). Optimization of carbon dioxide fixation by Chlorella vulgaris cultivated in a membrane-photobioreactor. Chemical Engineering \& Technology: Industrial Chemistry-Plant Equipment-Process Engineering-Biotechnology, 30(8), 1094-1099.
[8]. Arata, S., Strazza, C., Lodi, A., \& Del Borghi, A. (2013). Spirulina platensis culture with flue gas feeding as a cyanobacteria-based carbon sequestration option. Chemical Engineering \& Technology, 36(1), 91-97.

[9]. Carvalho, J. C. M., Francisco, F. R., Almeida, K. A., Sato, S., \& Converti, A. (2004). Cultivation of arthrospira (spirulina) platensis (cyanophyceae) by fed-batch addition of ammonium chloride at exponentially increasing feeding rates 1. Journal of Phycology, 40(3), 589-597.

[10]. Zeng, X., Danquah, M. K., Zhang, S., Zhang, X., Wu, M., Chen, X. D., ... \& Lu, Y. (2012). Autotrophic cultivation of Spirulina platensis for CO2 fixation and phycocyanin production. Chemical Engineering Journal, 183, 192-197.

[11]. Soletto, D., Binaghi, L., Ferrari, L., Lodi, A., Carvalho, J. C. M., Zilli, M., \& Converti, A. (2008). Effects of carbon dioxide feeding rate and light intensity on the fed-batch pulsefeeding cultivation of Spirulina platensis in helical photobioreactor. Biochemical Engineering Journal, 39(2), 369-375.

[12]. Leema, J. M., Kirubagaran, R., Vinithkumar, N. V., Dheenan, P. S., \& Karthikayulu, S. (2010). High value pigment production from Arthrospira (Spirulina) platensis cultured in seawater. Bioresource technology, 101(23), 9221-9227.

[13]. Mehar, J., Shekh, A., Nethravathy, M. U., Sarada, R., Chauhan, V. S., \& Mudliar, S. (2019). Automation of pilot-scale open raceway pond: A case study of CO2-fed $\mathrm{pH}$ control on Spirulina biomass, protein and phycocyanin production. Journal of CO2 utilization, 33, 384393.

[14]. Ghoshal, D., Husic, H.D., Goyal, A., 2002. Dissolved inorganic carbon concentration mechanism in Chlamydomonas moewusii. Plant Physiol. Biochem. 40, 299-305. 
[15]. Riebesell, U., Schulz, K.G., Bellerby, R.J.G., Botros, M., Fritsche, P., Meyerhofer, M., Neill, C., Nondal, G., Oschlies, A., Wohlers, J., Zollner, E., 2007. Enhanced biological carbon consumption in a high CO2 ocean. Nature 450, 545-548.

[16]. Singh SP, Singh P. 2014. Effect of CO2 concentration on algal growth: A review. Renewable and Sustainable Energy Reviews, 38: 172-179.

[17]. Shabani, M. (2016). CO2 bio-sequestration by Chlorella vulgaris and Spirulina platensis in response to different levels of salinity and $\mathrm{CO} 2$. Proceedings of the International Academy of Ecology and Environmental Sciences, 6(2), 53.

[18]. Upendar, G., Singh, S., Chakrabarty, J., Ghanta, K. C., Dutta, S., \& Dutta, A. (2018). Sequestration of carbon dioxide and production of biomolecules using cyanobacteria. Journal of environmental management, 218, 234-244.

[19]. Tang, D., Han, W., Li, P., Miao, X., \& Zhong, J. (2011). CO2 biofixation and fatty acid composition of Scenedesmus obliquus and Chlorella pyrenoidosa in response to different CO2 levels. Bioresource technology, 102(3), 3071-3076.

[20]. De Oliveira, M. A. C. L., Monteiro, M. P. C., Robbs, P. G., \& Leite, S. G. F. (1999). Growth and chemical composition of Spirulina maxima and Spirulina platensis biomass at different temperatures. Aquaculture international, 7(4), 261-275.

\section{Cite this article as :}

Hetarth B. Patel, Hitesh A. Solanki, "Optimization of the Growth and Performance of Several Cynobacteria Species in a Pilot Scale Raceway Pond for CO2 BioSequestration", International Journal of Scientific Research in Science and Technology (IJSRST), Online ISSN : 2395-602X, Print ISSN : 2395-6011, Volume 8 Issue 6, pp. 497-509, November-December 2021. Available at

doi : https://doi.org/10.32628/IJSRST218676

Journal URL : https://ijsrst.com/IJSRST218676 